\title{
Perbandingan Desain Pembelajaran ASSURE dan PPSI untuk Meningkatkan Kemampuan Pemecahan Masalah Matematis dan Kemandirian Belajar
}

\author{
Rostina Sundayana \\ Program Studi Pendidikan Matematika, Institut Pendidikan Indonesia \\ Jalan Pahlawan No. 32 Sukagalih, Garut, Jawa Barat, Indonesia \\ sundayana.math@gmail.com
}

Artikel diterima: 05-12-2018, direvisi: 29-01-2019, diterbitkan: 31-01-2019

\begin{abstract}
Abstrak
Penelitian ini bertujuan untuk mengkaji peningkatan kemampuan pemecahan masalah dan kemandirian belajar matematika siswa kelas VII dengan menggunakan desain pembelajaran ASSURE. Penelitian ini menggunakan metode kuasi eksperimen, dengan desain kelompok kontrol pretes-postes. Pada kelompok kontrol, digunakan desain pembelajaran yang sedang berjalan yaitu desain Prosedur Pengembangan Sistem Instruksional (PPSI).Populasi dalam penelitian ini adalah siswa kelas VII SMP Negeri di Kabupaten Garut yang mencakup sekolah level bawah, tengah, dan atas.Dari masing-masing level tersebut, diambil sampel sebanyak tiga kelompok yaitu kelompok eksperimen 1 (siswa yang mendapat desain pembelajaran ASSURE dengan model Problem Based Learning/A-PBL); kelompok eksperimen 2 (siswa yang mendapat desain pembelajaran ASSURE dengan model Discovery Learning/A-DL) dan kelompok kontrol (siswa yang mendapat desain PPSI dengan model pembelajaran PBL dan DL). Dengan menggunakan teknik analisis data ANOVA, Kruskal-Wallis, Uji Tukey HSD, dan uji Perbandingan Berganda diperoleh kesimpulan dari hasil penelitian ini, secara umum bahwa: peningkatan kemampuan pemecahan masalah dan kemandirian belajar matematika siswa yang mendapat desain pembelajaran ASSURE lebih baik dari siswa yang mendapat PPSI. Kata Kunci: ASSURE, kemampuan pemecahan masalah, kemandirian belajar Matematika.

\section{The Comparison of ASSURE and PPSI Model as Instructional Design to Increase Mathematics Skills in Problem Solving and Self-Directed Learning Abstract}

This study is aimed at reviewing the increase of Junior High School Students' Mathematics skills in problem solving and Self-directed learning by using ASSURE design (Analyze learner characteristics; State standards and objectives; Select methods, media and materials; Utilize media and materials; Require learner participation; and Evaluate and revise). This study used experimental method with pretest-posttest control group design. The population in this study was grade VII students of State Junior High Schools located in Garut Regency consisting of schools with lower level, middle level, and top level. From the schools which had been randomly selected, three classes were also randomly selected to take as sample. The first two classes used ASSURE model as instructional design by applying Problem Based Learning (A$P B L)$ and Discovery Learning (A-DL) respectively. Meanwhile, the third class used conventional instructional design by applying Problem Based Learning and Discovery Learning (K-PBL/DL). By using ANOVA data analysis techniques, Kruskal-Wallis, Tukey HSD Test, and Multiple Comparison tests are concluded in general, the conclusion drawn based on the results of this study is that the increase of students' Mathematics skills in problem solving and Self-directed learning who were taught by using ASSURE model showed better results than those who were taught by using conventional model

Keyword: ASSURE, Problem Solving, Self-directed learning.
\end{abstract}




\section{Pendahuluan}

Pada umumnya proses pembelajaran matematika yang terjadi di Indonesia baru mampu mengembangkan kemampuan berpikir tahap rendah yang bersifat prosedural (Suryadi, 2005). Dengan kata lain, proses pembelajaran yang terjadi belum mampu mengembangkan kemampuan berpikir matematis siswa ke tingkat yang lebih tinggi. Salah satu upaya dapat dilakukan dengan mengembangkan serta menciptakan suasana belajar yang mendorong siswa melatih kemampuan pemecahan masalah matematis serta kemandirian belajarnya sehingga pembelajaran matematika lebih bermakna. Guru juga perlu mengupayakan pemilihan desain pembelajaran, strategi dan model pembelajaran, serta memperhatikan karakteristik siswa yang dihadapinya.

Kemandirian belajar merupakan proses dimana individu mengambil inisiatif dalam merencanakan, melaksanakan dan mengevaluasi sistem pembelajarannya (Merriam \& Caffarella, 1999). Kemandirian belajar ini penting sebagai pencapaian dan peningkatan kemampuan belajar siswa (Muhtadi \& Sukirwan, 2017). Selanjutnya menurut Kozma, Belle dan Williams (1978), Knowles (1989), Mocker \& Spear (1984) kemandirian belajar merupakan suatu proses belajar dimana setiap individu dapat mengambil inisiatif, dengan atau tanpa bantuan orang lain, dalam hal mendiagnosa kebutuhan belajar, merumuskan tujuan belajar, mengidentifikasi sumber-sumber belajar (baik berupa orang maupun bahan), memilih dan menerapkan strategi belajar yang sesuai bagi dirinya, serta mengevaluasi hasil belajarnya. Pannen $\mathrm{dkk}$ (2000) menegaskan bahwa ciri utama dalam belajar mandiri bukanlah ketiadaan guru atau teman sesama siswa, atau tidak adanya pertemuan tatap muka di kelas. Menurutnya, yang menjadi ciri utama dalam belajar mandiri adalah adanya pengembangan kemampuan siswa untuk melakukan proses belajar yang tidak tergantung pada faktor guru, teman, kelas dan lain-lain. Sementara itu, pada penelitian peneliti sebelumnya, diperoleh bahwa semakin tinggi tingkat kemandirian belajar siswa, maka semakin tinggi pula kemampuan pemecahan masalah matematis siswa (Sundayana, 2016).

Berdasarkan analisis peneliti, pada umumnya, di Indonesia desain pembelajaran yang digunakan adalah desain pembelajaran PPSI (Prosedur Pengembangan Sistem Instruksional) yaitu suatu model pengajaran yang terdiri atas komponen yang menitikberatkan pada tujuan pengajaran. Sehingga pengajaran selalu mengacu pada tujuan pendidikan khususnya tujuan instruksional. Adapun langkah-langkan desain pembelajaran PPSI antara lain: 1) Perumusan tujuan instruksional; 2) Pengembangan Alat Evaluasi; 3) Kegiatan Belajar; 4) Pengembangan Program Kegiatan; dan 5) Pelaksanaan Program.

Berdasarkan langkah-langkah desain pembelajaran PPSI di atas, jika diterapkan

Mosharafa: Jumal Pendidikan Matematika Volume 8, Nomor 1, Januari 2019 Copyright $\odot 2019$ Mosharafa: Jurnal Pendidikan Matematika 
dalam pembelajaran matematika ada beberapa kelemahan antara lain: 1) tidak memperhatikan bagaimana karakteristik siswa; hal ini penting dilakukan, sebab karakteristik siswa antara yang satu dengan yang lain berbeda-beda terutama gaya belajar siswa; 2) penggunaan media pembelajaran tidak terlalu diperhatikan, padahal konsep matematika pada umumnya bersifat abstrak, sehingga untuk mengajarkan konsep matematika pada siswa yang masih taraf berpikirnya konkret media pembelajaran masih diperlukan. (Darhim, 2014).

Dari penjelasan di atas, dalam pembelajaran matematika diperlukan suatu desain pembelajaran yang tidak hanya yang menitikberatkan pada tujuan pengajaran saja, namun juga memperhatikan karakteristik siswa dalam belajar, serta melibatkan aspek media pembelajaran dalam mata pelajaran matematika. Desain pembelajaran yang lebih berorientasi pada karakteristik siswa serta melibatkan pemanfaatan media pembelajaranya itu model desain pembelajaran ASSURE.

Model desain pembelajaran ASSURE dikembangkan oleh Smaldino, Lowther \&Russel (2005). Model desain pembelajaran ini merupakan singkatan dari komponen atau langkah penting yang terdapat di dalamnya yaitu: Analyze learner characteristics; State performance objectives); Select methods, media, and materials utilize; Utilize media and materials; Requires learner paticipation; Evaluation and revise.

\section{Mosharafa: Jurnal Pendidikan Matematika}

Volume 8, Nomor 1, Januari 2019

Copyright @ 2019 Mosharafa: Jurnal Pendidikan Matematika Model
Pembelajaran ASSURE memadukan berbagai aktivitas dalam pembelajaran Smaldino (2005) mengatakan Model Pembelajaran ASSURE merupakan sebuah prosedur panduan untuk perencanaan dan bimbingan pembelajaran yang mengkombinasikan antara materi, metode dan media. Selanjutnya dikatakan bahwa: "The ASSURE Model, on the other hand, is mean for the individual instructor to use when planing classroom use of media and technology".

Berikut uraian dari langkah-langkah Model pembelajaran ASSURE penulis paparkan sebagai berikut:

Analyze Learner, menurut Heinich (1996) siswa dapat dianalisis menyangkut (a) karakteristik umum siswa (umur, tingkat kemampuan, faktor budaya atau sosial ekonomi), (b) kompetensi khusus (pengetahuan, keterampilan, dan sikap siswa), (c) gaya belajar siswa (Auditori, kinestetik, visual).

State Objective, menurut Heinich (1996) disingkat dengan ABCD adalah yaitu (1) A (Audience), yaitu apa yang bisa dilakukan oleh siswa setelah pembelajaran; (2) B (Behavior), yaitu kata kerja operasional yang menggambarkan kemampuan siswa (audience) setelah pembelajaran; (3) C (Condition), yaitu pernyataan dari tujuan yang menyatakan performance (pelaksanaan) yang dapat diobservasi; (4) D (degree), yaitu menyatakan standar atau kriteria.

Select Methods, Media, and Materials, proses pemilihanmempunyai tiga langkah, yaitu: 1) memutuskan metode yang tepat 
untuk memberikan tugas pembelajaran; 2) memilih media pembelajaran yang sesuai untuk melaksanakan metode; dan 3) memilih, memodifikasi dan mendesain materi secara spesifik.

Utilize Media and Material (Menggunakan Media dan Materi), menurut Heinich (1996) direkomendasikan prosedur menggunakan media berdasarkan pada langkah " $5 \mathrm{P}$ " yang pembelajarannya berbasis guru atau berpusat pada siswa. "5P" tersebut adalah: 1) Preview the Materials; 2) Prepare Materials;3) Prepare the Environmental; 4) Prepare the Learner; 5) Prepare the Learning Experience.

Require Leaner Participation (Membutuhkan Partisipasi Siswa), Guru seharusnya merealisasikan partisipasi aktif dari siswa di dalam proses pembelajaran. Menurut Jhon Dewey (dalam Heinich, 1996) berargumentasi bahwa reorganisasi dari kurikulum dan pembelajaran untuk membuat siswa berpartisipasi sebagai pusat bagian proses pembelajaran. Dalam proses pembelajaran matematika dikelas, para siswa secara kelompok memperhatikan pembelajaran berlangsung, dan memperhatikan tayangan pembelajaran.

Evaluate and Revise, Menurut Heinich (1996) bahwa Evaluasi dan Revisi merupakan komponen yang sangat penting untuk mengembangkan kualitas pembelajaran. Ada beberapa tujuan evaluasi, yaitu sebagai penilaian prestasi siswa, dan juga untuk mengevaluasi media dan metode. Meskipun evaluasi dilakukan 146 di akhir,tetapi evaluasi berlangsung terus selama proses pembelajaran. Evaluasi bukan akhir dari pembelajaran. Itu adalah titik awal berikutnya dan berlangsung terus dalam siklus Model Pembelajaran ASSURE.

Hasil penelitian mengenai penggunaan desain pembelajaran ASSURE belum begitu banyak dilakukan, Giarti (2012) melakukan penelitian mengenai penerapan model pembelajaran ASSURE untuk meningkatkan hasil belajar IPA siswa kelas VI SD Negeri 2 Bengle Kec. Wonosegoro-Boyollali. Hasil penelitian menunjukkan bahwa ketuntasan belajar siswa mencapai $100 \%$ dengan kenaikan minat belajar sebesar $83 \%$. Pada pelajaran matematika, Wibowo dkk. (2013) menunjukkan bahwa, terdapat perbedaan kemampuan menghitung luas bangun datar antara siswa yang diajar dengan menggunakan model pembelajaran ASSURE dan model pembelajaran langsung pada siswa kelas V Semester II SD Negeri se-Kecamatan Pracimantoro Tahun Ajaran 2012/2013, dan hasil belajar siswa yang diberi perlakuan model pembelajaran ASSURE lebih baik daripada hasil belajar siswa yang diberi perlakuan dengan model pembelajaran langsung. Pada tingkat SMP, penelitian yang dilakukan oleh Pamungkas (2014) mengenai kemampuan dan peningkatan berpikir kritis serta berpikir kreatif matematis siswa yang pembelajarannya menggunakan model pembelajaran ASSURE lebih baik daripada kemampuan siswa yang pembelajarannya dilaksanakan secara konvensional.

Mosharafa: Jurnal Pendidikan Matematika Volume 8, Nomor 1, Januari 2019 Copyright $\odot 2019$ Mosharafa: Jurnal Pendidikan Matematika 
Dari beberapa penelitian yang telah dilakukan mengenai penggunaan desain pembelajaran ASSURE tersebut, semuanya hanya menonjolkan aspek media pembelajaranya, tidak ada yang melibatkan variabel karakteristik siswa terutama gaya belajar siswa. Penelitian yang akan penulis lakukan, melibatkan variabel gaya belajar siswa, sehingga penelitian yang akan penulis lakukan bukan penelitian duplikasi namun merupakan suatu kebaruan.

\section{Metode}

Populasi dalam penelitian ini adalah seluruh siswa kelas VII di Kabupaten Garut yang diklasifikasikan menjadi tiga level sekolah (bawah, tengah, dan atas), kemudian dilakukan pengambilan sampel dengan cara stratified sampling. Pertama, dari masing-masing level sekolah, dipilih secara acak satu sekolah; kedua, dari tiga sekolah yang terpilih pada tahap pertama dipilih tiga kelas secara acak dari beberapa kelas VII yang pararel. Selanjutnya untuk menentukan kelas mana yang dijadikan dua kelas eksperimen maupun satu kelas kontrol dipilih secara acak. Kelas eksperimen 1 (desain pembelajaran ASSURE dengan model Problem Based Learning/A-PBL) berjumlah 101 siswa (34 siswa masing-masing pada sekolah level bawah dan tengah, 33 siswa pada level atas); Kelas eksperimen 2 (desain pembelajaran ASSUREdengan model Discovery Learning/A-DL) sebanyak 103 siswa (35 siswa pada sekolah level bawah, dan masing-masing 34 siswa pada level tengah dan atas); serta kelas kontrol (desain pembelajaran PPSI dengan model pembelajaran PBL dan DL) sebanyak 99 siswa (33 siswa pada sekolah level bawah, 32 siswa pada level tengah, dan 34 siswa pada level atas);. Jadi jumlah sampel yang dijadikan objek dalam penelitian ini sebanyak sembilan kelas, dengan jumlah siswa total 303 siswa.

Pada pelaksanaan penelitian, peneliti dibantu oleh 3 orang asisten peneliti dan 3 orang guru matematika yang mempunyai jenjang pendidikan yang sama, yaitu Magister Pendidikan, serta dibantu oleh 3 orang observer dari mahasiswa tingkat akhir jurusan Pend. Matematika. Para asisten peneliti bertugas memberikan pembelajaran di kelas eksperimen, guru matematika mengajar pada kelas kontrol, sedangkan observer bertugas untuk mengobservasi, mencatat berbagai hal sesuai dengan lembar observasi yang telah disediakan. Sebelum pelaksanaan penelitian dimulai, terlebih dahulu, meneliti memberikan gambaran dan pelatihan mengenai penggunaan desain pembelajaran ASSURE, serta model pembelajaran yang diterapkan.

Penelitian ini melibatkan dua jenis instrumen, yaitu tes dan nontes. Untuk mengukur kemampuan pemecahan masalah matematis siswa diberikan tes pemecahan masalah berupa soal-soal tentang materi yang diajarkan meliputi himpunan, garis dan sudut.Sedangkan instrumen non tes berupa skala kemandirian belajar matematika dan angket gaya belajar siswa yang hanya

\section{Mosharafa: Jumal Pendidikan Matematika}


diberikan pada kelompok siswa yang mendapat desain pembelajaran ASSURE. Pada penggunaan desain pembelajaran ASSURE, siswa dikelompokkan selain berdasarkan tingkat kognitif dan kemandirian belajar siswa, juga dikelompokkan berdasarkan gaya belajar siswa yang dimilikinya.

. Indikator yang menunjukkan kemampuan pemecahan masalah matematis merujuk pada pendapat Sumarmo (1987) antara lain:
a. Mengidentifikasi
unsur-unsur yangdiketahui, yang ditanyakan, dan kecukupan unsur yang diperlukan;
b. Merumuskan masalah matematik atau menyusun model matematik;
c. Menerapkan strategi untuk menyelesaikan berbagai masalah

(sejenis dan masalah baru) dalam atau di luar matematika;

d. Menjelaskan atau menginterpretasikan hasil sesuai permasalahan asal; dan

e. Menggunakan matematika secara bermakna.

Instrumen penelitian tersebut, sebelum digunakan terlebih dahulu dilakukan ujicoba dengan hasil memiliki validitas dan reliabilitas yang baik.

\section{Hasil dan Pembahasan}

Secara deskriptif statistika, mengenai kemampuan pemecahan masalah siswa pada sebelum, sesudah, serta peningkatannya disajikan pada tabel berikut:

Tabel 1.

Deskripsi rekapitulasi hasil kemampuan pemecahan masalah matematis

\begin{tabular}{|c|c|c|c|c|c|c|c|c|}
\hline \multirow{2}{*}{$\begin{array}{c}\text { Level } \\
\text { Sekolah }\end{array}$} & \multirow[t]{2}{*}{ Kelompok } & \multirow{2}{*}{$\begin{array}{c}\text { Banyak } \\
\text { siswa (n) }\end{array}$} & \multicolumn{2}{|c|}{ Pretes } & \multicolumn{2}{|c|}{ Postes } & \multicolumn{2}{|c|}{ Peningkatan } \\
\hline & & & Mean & $\begin{array}{c}\text { Std. } \\
\text { Deviation }\end{array}$ & Mean & $\begin{array}{c}\text { Std. } \\
\text { Deviation }\end{array}$ & Mean & $\begin{array}{c}\text { Std. } \\
\text { Deviation }\end{array}$ \\
\hline \multirow[t]{4}{*}{ Bawah } & A-PBL & 34 & 5,03 & 4,25 & 14,91 & 7,21 & 0,29 & 0,15 \\
\hline & $A-D L$ & 35 & 5,54 & 3,08 & 15,40 & 5,04 & 0,29 & 0,10 \\
\hline & K-PBL/DL & 33 & 5,42 & 2,18 & 12,00 & 5,59 & 0,19 & 0,13 \\
\hline & Total & 102 & 5,33 & 3,26 & 14,14 & 6,14 & 0,26 & 0,14 \\
\hline \multirow[t]{4}{*}{ Tengah } & A-PBL & 34 & 9,50 & 2,25 & 20,65 & 2,25 & 0,37 & 0,06 \\
\hline & $A-D L$ & 34 & 9,29 & 2,44 & 21,12 & 3,55 & 0,39 & 0,09 \\
\hline & K-PBL/DL & 32 & 9,03 & 3,35 & 16,97 & 4,49 & 0,26 & 0,08 \\
\hline & Total & 100 & 9,28 & 2,69 & 19,63 & 3,95 & 0,34 & 0,09 \\
\hline \multirow[t]{4}{*}{ Atas } & A-PBL & 33 & 9,64 & 3,86 & 30,76 & 5,47 & 0,71 & 0,14 \\
\hline & $A-D L$ & 34 & 9,65 & 3,60 & 25,29 & 6,65 & 0,53 & 0,18 \\
\hline & K-PBL/DL & 34 & 9,47 & 2,68 & 21,35 & 4,49 & 0,39 & 0,13 \\
\hline & Total & 101 & 9,58 & 3,38 & 25,75 & 6,76 & 0,54 & 0,20 \\
\hline \multirow[t]{4}{*}{ Total } & A-PBL & 101 & 8,04 & 4,13 & 22,02 & 8,45 & 0,45 & 0,22 \\
\hline & $A-D L$ & 103 & 8,14 & 3,58 & 20,55 & 6,60 & 0,40 & 0,16 \\
\hline & K-PBL/DL & 99 & 7,98 & 3,29 & 16,82 & 6,19 & 0,28 & 0,14 \\
\hline & Total & 303 & 8,05 & 3,67 & 19,82 & 7,45 & 0,38 & 0,19 \\
\hline
\end{tabular}


Berdasarkan tabel di atas, secara umum kemampuan pemecahan masalah matematis siswa pada awal penelitian (pretes) antara kelompok A-PBL, A-DL, maupun K-PBL/DL menunjukkan skor ratarata yang merata yaitu antara 7,98-8,14. Namun setelah diberi perlakuan yang berbeda, skor pencapaian (postes) menunjukkan skor rata-rata yang berbeda yaitu antara 16,82-22,02. Begitu pula dengan peningkatan kemampuan pemecahan masalah matematis siswa, rata-rata skor peningkatan berkisar antara $0,28-0,45$. Kondisi tersebut, berlaku pula pada tiap level sekolah (bawah, tengah, atas). Namun demikian, kita perlu menguji secara statistik, mengenai signifikansi perbedaan yang muncul.Sedangkan kemandirian belajar, diperlihatkan pada Tabel 2 berikut:

Tabel 2.

Deskripsi rekapitulasi hasil kemampuan pemecahan masalah matematis

\begin{tabular}{|c|c|c|c|c|c|c|c|c|}
\hline \multirow{2}{*}{$\begin{array}{c}\text { Level } \\
\text { Sekolah }\end{array}$} & \multirow[t]{2}{*}{ Kelompok } & \multirow{2}{*}{$\begin{array}{c}\text { Banyak } \\
\text { siswa (n) }\end{array}$} & \multicolumn{2}{|c|}{ Pretes } & \multicolumn{2}{|c|}{ Postes } & \multicolumn{2}{|c|}{ Peningkatan } \\
\hline & & & Mean & $\begin{array}{c}\text { Std. } \\
\text { Deviation }\end{array}$ & Mean & $\begin{array}{c}\text { Std. } \\
\text { Deviation }\end{array}$ & Mean & $\begin{array}{c}\text { Std. } \\
\text { Deviation }\end{array}$ \\
\hline \multirow[t]{4}{*}{ Bawah } & $A-P B L$ & 34 & 5,03 & 4,25 & 14,91 & 7,21 & 0,29 & 0,15 \\
\hline & A-DL & 35 & 5,54 & 3,08 & 15,40 & 5,04 & 0,29 & 0,10 \\
\hline & K-PBL/DL & 33 & 5,42 & 2,18 & 12,00 & 5,59 & 0,19 & 0,13 \\
\hline & Total & 102 & 5,33 & 3,26 & 14,14 & 6,14 & 0,26 & 0,14 \\
\hline \multirow[t]{4}{*}{ Tengah } & $A-P B L$ & 34 & 9,50 & 2,25 & 20,65 & 2,25 & 0,37 & 0,06 \\
\hline & $A-D L$ & 34 & 9,29 & 2,44 & 21,12 & 3,55 & 0,39 & 0,09 \\
\hline & K-PBL/DL & 32 & 9,03 & 3,35 & 16,97 & 4,49 & 0,26 & 0,08 \\
\hline & Total & 100 & 9,28 & 2,69 & 19,63 & 3,95 & 0,34 & 0,09 \\
\hline \multirow[t]{4}{*}{ Atas } & A-PBL & 33 & 9,64 & 3,86 & 30,76 & 5,47 & 0,71 & 0,14 \\
\hline & A-DL & 34 & 9,65 & 3,60 & 25,29 & 6,65 & 0,53 & 0,18 \\
\hline & K-PBL/DL & 34 & 9,47 & 2,68 & 21,35 & 4,49 & 0,39 & 0,13 \\
\hline & Total & 101 & 9,58 & 3,38 & 25,75 & 6,76 & 0,54 & 0,20 \\
\hline \multirow[t]{4}{*}{ Total } & $A-P B L$ & 101 & 8,04 & 4,13 & 22,02 & 8,45 & 0,45 & 0,22 \\
\hline & $A-D L$ & 103 & 8,14 & 3,58 & 20,55 & 6,60 & 0,40 & 0,16 \\
\hline & K-PBL/DL & 99 & 7,98 & 3,29 & 16,82 & 6,19 & 0,28 & 0,14 \\
\hline & Total & 303 & 8,05 & 3,67 & 19,82 & 7,45 & 0,38 & 0,19 \\
\hline
\end{tabular}

Berdasarkan tabel di atas, secara umum kemandirian belajar matematika siswa pada awal penelitian (pretes) antara kelompok A-PBL, A-DL, maupun K-PBL/DL menunjukkan skor rata-rata yang merata yaitu antara 82,68-83,59. Namun setelah diberi perlakuan yang berbeda, skor pencapaian (postes) menunjukkan skor rata-rata yang berbeda yaitu antara 93,50102,21. Begitu pula dengan peningkatan kemandirian belajar siswa, rata-rata skor antara 0,17-0,30. Seperti halnya hasil mengenai kemampuan pemecahan masalah matematis sebelumnya, kondisi ini pun, berlaku pada tiap level sekolah (bawah, tengah, atas). Namun demikian, kita perlu menguji secara statistik, mengenai signifikansi perbedaan yang muncul. 


\section{A. Peningkatan \\ Pemecahan (PnKPMM)}

Berdasarkan uji ANOVA yang hasilnya menunjukkan pada setiap level sekolah, ditemukan adanya perbedaan yang signifikan. Untuk mengetahui perbedaan pada masing-masing level sekolah, dilakukan uji uji Tukey HSD. Adapun hasil pengujian disajikan pada tabel berikut:

Tabel 3.

Rekapitulasi Uji Tukey HSD Perbedaan PnKPMM

\begin{tabular}{clccc}
\hline $\begin{array}{c}\text { Level } \\
\text { Sekolah }\end{array}$ & \multicolumn{1}{c}{$\begin{array}{c}\text { Pasangan-Model } \\
\text { Pembelajaran }\end{array}$} & $\begin{array}{c}\text { Selisih Rata- } \\
\text { rata }\end{array}$ & Sig. & Ho \\
\hline \multirow{2}{*}{ Bawah } & $(\mathrm{A}-\mathrm{PBL})-(\mathrm{A}-\mathrm{DL})$ & 0,00 & 0,998 & Terima Ho \\
& $(\mathrm{A}-\mathrm{PBL})-(\mathrm{K}-\mathrm{PBL} / \mathrm{DL})$ & $0,10^{*}$ & 0,006 & Tolak Ho \\
\multirow{5}{*}{ Tengah } & $(\mathrm{A}-\mathrm{DL})-(\mathrm{K}-\mathrm{PBL} / \mathrm{DL})$ & $0,10^{*}$ & 0,007 & Tolak Ho \\
& $(\mathrm{A}-\mathrm{PBL})-(\mathrm{A}-\mathrm{DL})$ & 0,02 & 0,451 & Terima Ho \\
& $(\mathrm{A}-\mathrm{PBL})-(\mathrm{K}-\mathrm{PBL} / \mathrm{DL})$ & $0,10^{*}$ & 0,000 & Tolak Ho \\
& $(\mathrm{A}-\mathrm{DL})-(\mathrm{K}-\mathrm{PBL} / \mathrm{DL})$ & $0,13^{*}$ & 0,000 & Tolak Ho \\
\multirow{5}{*}{ Atas } & $(\mathrm{A}-\mathrm{PBL})-(\mathrm{A}-\mathrm{DL})$ & $0,18^{*}$ & 0,000 & Tolak Ho \\
& $(\mathrm{A}-\mathrm{PBL})-(\mathrm{K}-\mathrm{PBL} / \mathrm{DL})$ & $0,32^{*}$ & 0,000 & Tolak Ho \\
& $(\mathrm{A}-\mathrm{DL})-(\mathrm{K}-\mathrm{PBL} / \mathrm{DL})$ & $0,14^{*}$ & 0,001 & Tolak Ho \\
\multirow{2}{*}{ Total } & $(\mathrm{A}-\mathrm{PBL})-(\mathrm{A}-\mathrm{DL})$ & 0,05 & 0,090 & Terima Ho \\
& $(\mathrm{A}-\mathrm{PBL})-(\mathrm{K}-\mathrm{PBL} / \mathrm{DL})$ & $0,17^{*}$ & 0,000 & Tolak Ho \\
& $(\mathrm{A}-\mathrm{DL})-(\mathrm{K}-\mathrm{PBL} / \mathrm{DL})$ & $0,12^{*}$ & 0,000 & Tolak Ho \\
\hline
\end{tabular}

Dari hasil uji Tukey HSD tersebut, diperoleh kesimpulan bahwa secara umum perbandingan rata-rata PnKPMM antara kelompok siswa A-PBL dengan kelompok siswa A-DL, tidak menunjukkan adanya perbedaan yang signifikan, Namun keduanya mempunyai rata-rata PnKPMM yang lebih baik dari siswa kelompok K-(PBL dan DL).Munculnya perbedaan rata-rata PnKPMM dari ketiga kelompok hanya pada siswa level sekolah atas, perbandingan rata-rata PnKPMM siswa kelompok A-PBL lebih baik dari kelompok A-DL, dan Kelompok A-DL lebih baik dari kelompok $\mathrm{K}-(\mathrm{PBL}$ dan $\mathrm{DL})$.

\section{B. Peningkatan Kemandirian Belajar Matematika}

Berdasarkan pengujian normalitas data, sebaran data pada level siswa bawah dan atas terdapat sebaran data yang berdistribusi tidak normal, sedangkan pada sekolah level tengah seluruhnya berdistribusi normal. Setelah dilakukan pengujian dengan ANOVA dan KruskalWallis, pada setiap kelompok menunjukkan adanya perbedaan peningkatan kemandirian belajar. Selanjutnya untuk mengetahui perbedaan PnKBM pada kelompok level sekolah bawah dan atas, dilakukan uji perbandingan berganda, sedangkan pada sekolah level tengah menggunakan uji

Mosharafa: Jumal Pendidikan Matematika Volume 8, Nomor 1, Januari 2019 Copyright $\odot 2019$ Mosharafa: Jurnal Pendidikan Matematika 
lanjut ANOVA menggunakan uji Tukey pada tabel berikut:

HSD. Adapun hasil pengujian disajikan

Tabel 4.

Rekapitulasi Uji Perbandingan Berganda dan Uji Tukey HSD Perbedaan PnKBM Berdasarkan Level Sekolah

\begin{tabular}{|c|c|c|c|c|c|c|}
\hline $\begin{array}{c}\text { Level } \\
\text { Sekolah }\end{array}$ & $\begin{array}{c}\text { Pasangan-Model } \\
\text { Pembelajaran }\end{array}$ & $\begin{array}{c}\text { Selisih } \\
\text { Rata-rata }\end{array}$ & $\begin{array}{c}\text { Selisih } \\
\text { Mean } \\
\text { Rank }\end{array}$ & Sig. & Nilai Kritis & $\begin{array}{l}\text { Interpre- } \\
\text { tasi }\end{array}$ \\
\hline \multirow{3}{*}{ Bawah } & $(A-P B L)-(A-D L)$ & & 3,77 & & 17,057 & Terima Ho \\
\hline & $(\mathrm{A}-\mathrm{PBL})-(\mathrm{K}-\mathrm{PBL} / \mathrm{DL})$ & & $19,36^{*}$ & & 17,310 & Tolak Ho \\
\hline & $(A-D L)-(K-P B L / D L)$ & & 15,59 & & 17,188 & Terima Ho \\
\hline \multirow[t]{3}{*}{ Tengah } & $(A-P B L)-(A-D L)$ & 0,037 & & 0,474 & & Terima Ho \\
\hline & $(\mathrm{A}-\mathrm{PBL})-(\mathrm{K}-\mathrm{PBL} / \mathrm{DL})$ & $0,103^{*}$ & & 0,005 & & Tolak Ho \\
\hline & $(A-D L)-(K-P B L / D L)$ & 0,066 & & 0,107 & & Terima Ho \\
\hline \multirow[t]{3}{*}{ Atas } & $(A-P B L)-(A-D L)$ & & 13,53 & & 17,141 & Terima Ho \\
\hline & $(\mathrm{A}-\mathrm{PBL})-(\mathrm{K}-\mathrm{PBL} / \mathrm{DL})$ & & $41,25^{*}$ & & 17,141 & Tolak Ho \\
\hline & (A-DL)-(K-PBL/DL) & & $27,72 *$ & & 17,013 & Tolak Ho \\
\hline
\end{tabular}

Dari hasil pengujian Perbandingan Berganda dan Uji Tukey HSD tersebut, diperoleh kesimpulan sebagai berikut:

a. Pada level sekolah kategori bawah dan tengah, perbandingan PnKBM antara siswa yang mendapatdesain-model pembelajaran $\mathrm{A}-\mathrm{PBL}$ dengan $\mathrm{A}-\mathrm{DL}$, tidak menunjukkan adanya perbedaan yang singnifikan; Begitu pula perbandingan PnKBM antara siswa yang mendapat A$\mathrm{DL}$ dengan kelompok K-(PBL dan DL) tidak menunjukkan adanya perbedaan. Namun, perbandingan PnKBM antara siswa yang mendapat A-PBL dengan kelompok K-(PBL dan DL), menunjukkan adanya perbedaan yang signifikan, dengan kelompok A-PBL lebih baik kelompok K-(PBL dan DL).

b. Pada level sekolah kategori atas, perbandingan PnKBM antara kelompok A-PBL dengan kelompok A-DL, tidak menunjukkan adanya perbedaan yang

\section{Mosharafa: Jumal Pendidikan Matematika}

Volume 8, Nomor 1, Januari 2019

Copyright @ 2019 Mosharafa: Jurnal Pendidikan Matematika singnifikan; Namun keduanya lebih baik dari siswa pada kelompok K-(PBL dan $\mathrm{DL})$.

\section{Pembahasan}

Berdasarkan hasil pengujian sebelumnya, diketahui bahwa peningkatan kemampuan pemecahan masalah dan kemandirian belajar matematika siswa yang mendapat desain ASSURE lebih baik dari pada siswa yang mendapat desain konvensional. Berdasarkan kategori Hake (1999) yang dimodifikasi Sundayana (2014:151), secara umum untuk peningkatan kemampuan pemecahan masalah matematika pada kelompok desain ASSURE mengalami peningkatan kategori sedang yaitu kelompok A-PBL mengalami peningkatan mencapai 0,45 (sedang); kelompok A-DL mencapai 0,40 (sedang), namun untuk kelompok kontrol hanya mencapai 0,28 (rendah). Hasil penelitian ini sesuai dengan yang 151 
dilakukan Sumartini (2016), Nadhifah, Afriansyah (2016) bahwa penggunaan model PBL dapat meningkatkan kemampuan pemecahan masalah.

Begitu pula untuk peningkatan kemandirian belajar matematika, secara umum pada kelompok A-PBL mengalami peningkatan kemandirian belajar mencapai 0,30 (sedang); kelompok A-DL mencapai 0,26 (rendah), namun untuk kelompok kontrol hanya mencapai 0,17 (rendah).

Ada beberapa hal yang menyebabkan hasil penelitian tersebut terjadi, antara lain sintak pembelajaran, sikap siswa dalam belajar, dan kemampuan awal matematika siswa. Setiap tahapan-tahapan Strategi PBL dapat menumbuhkan keaktifan dan kemandirian siswa dalam proses pembelajaran terutama dalam pemecahan suatu masalah dan otonom yang percaya pada keterampilan intelektual mereka sendiri, lingkungan belajar menekankan pada peran sentral siswa bukan pada guru. Kegiatan guru lebih berperan sebagai motivator, organisator, fasilitator dan evaluator. Hal ini akan menimbulkan rasa penasaran siswa terhadap masalah yang sedang dihadapi sehingga muncul keaktifan siswa untuk mencoba mencari pemecahannya (Rusman, 2012: 243).

Pada awal pelaksanaan pembelajaran dengan menggunakan PBL, siswa masih terlihat aktifitas dalam memahami masalah yang diberikan guru masih kurang meresponnya, malu bertanya dan tidak percaya diri dalam mengemukakan pendapat, masih terdapat beberapa siswa 152 yang cenderung masih mengandalkan teman dalam menyelesaikan tugas. Namun setelah beberapa kali pertemuan menggunakan $\mathrm{PBL}$, siswa mulai terbiasa dalam melakukan langkah-langkah PBL tersebut. Selain itu, peneliti juga memberikan bimbingan dengan cara mendekati siswa-siswa yang masih pasif untuk supaya berperan aktif dengan kelompoknya; selain itu, memberikan penghargaan pada kelompok yang paling aktif maju di depan kelas. Untuk kelompok siswa yang mendapat desain pembelajaran ASSURE, kelebihan dari kelompok siswa yang mendapat desain pembelajaran PPSI yaitu dalam penataan kelompok, yang mendapatkan desain pembelajaran ASSURE dikelompokkan secara homogen dalam hal gaya belajarnya (Auditori, Kinestetik, dan Visual), sedangkan desain konvensionalnya secara gaya belajar merupakan kelompok yang heterogen.

\section{Penutup}

Secara umum peningkatan kemampuan pemecahan masalah dan kemandirian belajar matematika siswa yang menggunakan desain pembelajaran ASSURE lebih baik dari siswa yang menggunakan desain pembelajaran PPSI. Rekomendasi dari penelitian ini adalah penggunaan desain pembelajaran ASSURE dapat digunakan pada setiap level untuk meningkatkan kemampuan pemecahan masalah matematis, serta untuk meningkatkan kemandirian belajar matematika. 


\section{Daftar PUStaka}

Darhim. (2014). Modul Media Pendidikan Matematika. Bandung: Setiabudi.

Giarti, S. (2012). Penerapan Model Pembelajaran ASSURE Untuk Meningkatkan Hasil BelajarIPA Siswa Kelas VI SD Negeri 2 Bengle Kecamatan Wonosegoro Boyolali. http://repository.library.uksw.edu/jsp ui/bitstream/123456789/3192/2/ART Sri\%20Giarti Penerapan\%20Model $f$ ull\%20text.pdf (25 Maret 2018).

Heinich, et.al. (1996). Instructional Media and Technologies for Learning. Tokyo: Prentice-Hall, Inc A Simon \& Schuster Company.

Knowles. (1989). The Adult Learner A Neglected Species. Third Edition. Houston: Gulf Publishing Company.

Kozma, RB, Belle, LW, William, GW. (1978). Instructional Techniques in Higher Education. New Jersey: Educational Technology Publications.

Merriam, S. B., Caffarella, R. S., \& Baumgartner, L. M. (1999). Learning in adulthood: a comprehensive guide. SanFrancisco: John Wiley \& Sons, Inc. 1999.

Mocker \& Spear. (1984). The organizing circumstance: Environmental determinants in self-directed learning. Adult Education Quarterly. 1984. 35: 1-1.

Muhtadi, D. \& Sukirwan. (2017). Implementasi Pendidikan Matematika Realistik (PMR) untuk Meningkatkan Kemampuan Berpikir Kreatif
Matematik dan Kemandirian Belajar Peserta Didik. Mosharafa: Jurnal Pendidikan Matematika, 6(1), 1-12.

Nadhifah, G. \& Afriansyah, E.A. (2016). Peningkatan Kemampuan Pemecahan Masalah Matematis Siswa dengan Menerapkan Model Pembelajaran Problem Based Learning dan Inquiry. Mosharafa: Jurnal Pendidikan Matematika, 5(1), 33-44.

Pamungkas, S.R. (2014). Peningkatan kemampuan berpikir kritis dan kreatif matematis siswa SMP melalui model pembelajaran ASSURE. Universitas Pendidikan Indonesia: Tesis. Tidak dipublikasikan.

Pannen, Paulina dkk. (2000). Konstruktivisme Dalam Pembelajaran. Jakarta: Departemen Pendidikan Nasional.

Rusman. (2012). Model-Model Pembelajaran Mengembangkan Profesionalisme Guru. Jakarta: PT. Rajagrafindo Persada.

Smaldino, S. E, Lowther. D. L, \& Russel. J. D. (2005). Instructional Technologyand Media for (Teknologi Pembelajaran dan Media untuk Belajar). Jakarta: Kencana.

Sumarmo, U. (1987). Kemampuan dan Penalaran Matematika Siswa SMA Dikaitkan dengan Kemampuan Penalaran Logik Siswa dan Beberapa Unsur Proses Belajar Mengajar. Disertasi pada PPs UPI Bandung: tidak diterbitkan.

Sumartini, T.S. (2016). Peningkatan Kemampuan Pemecahan Masalah 
Matematis Siswa melalui

Pembelajaran Berbasis Masalah.

Mosharafa: Jurnal Pendidikan

Matematika, 5(2), 145-158.

Sundayana, R. (2014). Statistika Penelitian

Pendidikan. Bandung: Alfabeta.

Sundayana, R. (2016). Kaitan antara Gaya

Belajar, Kemandirian Belajar, dan

Kemampuan Pemecahan Masalah

Siswa SMP dalam Pelajaran

Matematika. Mosharafa: Jurnal

Pendidikan Matematika, 5(2), 75-84.

Suryadi, D. (2005). Penggunaan

Pendekatan Pembelajaran Tidak

Langsung serta Pendekatan Gabungan

Langsung dan Tidak langsung dalam

Rangka Meningkatkan Kemampuan

Berpikir Matematika Tingkat Tinggi

Siswa SLTP. Disertasi pada PPs UPI

Bandung: tidak dipublikasikan.

Wibowo, Ahmad Sri, dkk. (2013). Pengaruh

Model Pembelajaran ASSURE

terhadap Kemampuan Menghitung

Luas Bangun Datar Bagi Siswa Kelas V

SD., Palembang. 2013.

http://portalgaruda.org/article.php?ar ticle $=107909 \& \mathrm{val}=4065$ (25 Maret 2018)

\section{Riwayat Hidup PenUlis}

\section{Dr. Rostina Sundayana, M.Pd.}

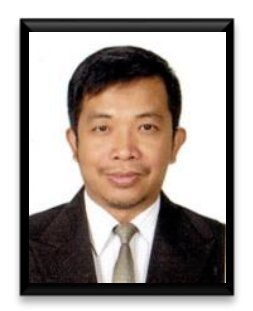

Lahir di Garut, 28 Desember 1966. Dosen LLDIKTI Wil. IV, dpk. IPI Garut. Lulusan S-3 Pendidikan Matematika UPI, Bandung. 